\title{
Supporting Traditional Educational Process with E-Learning Tools
}

\author{
Žolt Namestovski*, Márta Takács ${ }^{* * *}$, Branka Arsović*** \\ *University of Novi Sad, Hungarian Language Teacher Training Faculty, Subotica, Serbia \\ ** Óbuda University, John von Neumann Faculty of Informatics, Budapest, Hungary, \\ ${ }^{* * *}$ University of Kragujevac, Teacher Training Faculty, Užice, Serbia \\ zsolt.namesztovszki@magister.uns.ac.rs, takacs.marta@nik.uni-obuda.hu, arsovic@sbb.sr
}

\begin{abstract}
In the last few years the role and the significance of the work forms supported with computers, networks and virtual environments increased. The reason for this is technological development and the need to involve computer-based support besides the traditional education. This paper presents several methods of using e-learning tools such as Moodle, the free and open-source Course Management System and WordPress, the platform for free publishing and blogging.
\end{abstract}

Keywords - education, e-learning, Moodle, WordPress

\section{INTRODUCTION}

The most significant problems which modern pedagogy meets do not provide sufficient feedback and inactivity of students. To eliminate the above-mentioned weaknesses, one has to look for new ways of organizing and working up the educational contents.

One possible solution was programmed teaching. Programmed teaching involved programmed teaching material (textbook) and/or the implementation machine for learning and teaching. Programmed teaching was developed in the 1960s on the border of cybernetics and didactics. Joint action and with the implementation of the latest developments created a new environment for learning and teaching. This environment was based on the continued management of learning, feedback information and confirmation. The contents are separated into smaller parts, which gradually build on each other (step by step) display information and ask questions. The student answers the question and then follows the confirmation of the answer.

The programmed teaching can divided into:

- Linear structure

- The tree structure

- Elastic structure

The opportunities offered by the computer utilized at most in elastic structure.

The concept e-learning is a broad term. There are several teaching models, which are based on ICT technology, the interactivity of computer and computer network. It includes the teaching/learning at schools, distance learning, adult education, open education and professional training.
According to the above definitions, it can be seen that elearning appears in several forms and activities, of which the most important ones are:

- Teaching in the classroom, which is supported by computer tools

- Distance learning supporting by ICT tools

- Combined learning (blended learning) in higher education

- Web conferences and seminars (distance learning)

- Teaching with TV, especially the digital broadcast, which provides interactive features

- Professional seminars in companies

- Independent learning via computers, multimedia and web content

- Learning by multimedia educational software

- Learning supported by mobile technologies

If e-learning is analyzed as a model or a process, there are different phases of development [2]:

- Traditional (frontal) education

- Education supporting by ICT tools

- Hybrid education

- Online education

E-learning, in most cases, means learning supported with ICT tools. The role of the participants in this form of learning is changing significantly.

The role of the traditional teacher, in the e-learning environment are divided into a tutor, mentor and designer. For tutors, mentors and designers one of the most important tasks is to create and maintain the motivation on an appropriate level, which is achieved by constructing the tasks and goals to be accomplished in a short period of time. Because of the specificity of elearning, instructional materials must be uniquely designed. Textbooks, workbooks, materials for presentation and demonstration that are used in traditional learning, can be applied only to a limited extent. For successful learning, it is necessary to design unique educational materials. These materials are divided into smaller modules, support independent learning, and contain information and instructions that will help the learning process. The curriculum should be prepared before starting the course, because during the course the modification of materials may prove to be difficult [1], [3]. 
For students, the greatest obstacle in an e-learning environment is the lack of motivation. The source of motivation (individual motivation, social motivation) is irrelevant, but participants who do not appropriate motivation will not be successful in these models of education and learning. The lack of basic competencies and lack of skills for using ICT tools are also significant obstacles. On the other hand, students need to be ready and willing to organize their own learning process.

\section{MOODLE APPLICATIONS}

Moodle is a Course Management System (CMS), also known as a Learning Management System (LMS) or a Virtual Learning Environment (VLE). It is a free web application that educators can use to create effective online learning sites [6], [8].

Moodle 2.0 has a language pack for 112 languages. Moodle is a free and open source software that was optimized for supporting e-learning. The software was designed in PHP language with support of Apache and MySQL. In December 2011 it had a user base of 72,177 registered and verified sites, serving 57,112,669 users in 5.8 million courses [4].

The courses (subjects) are the basic units of content. The teaching, the communication, and also the grading of students all happen within the courses.

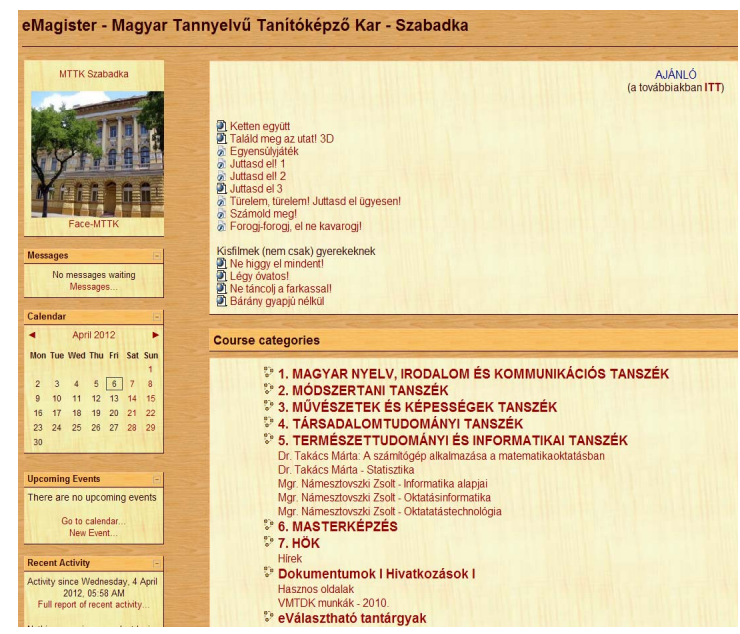

Figure 1. Moodle Course Management System installed for (purpose) the use of the Hungarian Language Teacher Training Faculty www.e.magister.uns.ac.rs

In the Moodle environment the roles and rights are exactly defined. Everyone who logs into Moodle has no special privileges until they are allocated roles by the administrator according to their needs in the individual courses or contexts [8].

There are the following roles:

- Administrator: the primary administrator created when the site was installed. The role of the administrator is assigned by another administrator. The administrator can perform any modifications in all of the courses.

- Course creator: they can create new courses and assign the role of teacher for these courses. The role of the course creator could typically be assigned to a master teacher, head of the department (head) or program coordinator [10].

- Teachers: they can teach their own courses. They can create and modify the teaching content and grade the students.

- Non-editing teacher: A non-editing teacher is able to only view and grade students' work within a course but may not alter or delete any of the activities or resources. This role might typically be given to a classroom assistant, for example [9].

- Students: A user with a Student role in Moodle can participate in course activities and view resources but not alter them or see the class grade book. They can see their own grades if the teacher has allowed this. When a student first joins Moodle they see all available courses. Once they have enrolled or been enrolled into at least one course they then only see their own courses in the My Courses section of the navigation block or via the My Home link [11].

- (Authenticated) Users: after registration users are assigned this role. Additional roles and participation in courses are assigned by administrator. Users can visit open courses and public information, send messages and blog.

- Guests: users with minimal privileges. They can enter in all courses which allow guest access. These courses usually include basic and public information about training, courses and/or institution.

Moodle is suitable for creating a learning environment, which is enriched with textual materials (web-based, Word documents and PDF), presentations (web-based, PowerPoint document), tables (web-based, Excel document), multimedia, experiments, chat, forum, online test, quiz, survey and wiki.

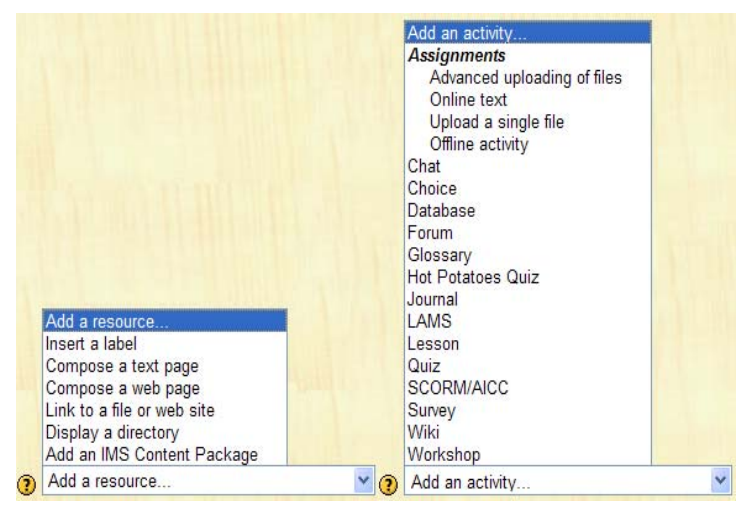

Figure 2. Possibilities to enrich learning material with resources and activities

In the Moodle system it is possible to realize the activity monitoring of each user. Reports can be created based on user or date and contains the login time, downloaded materials and opened links, online activities, results of tests and other statistics. This information appears in form of table, text and chart. 


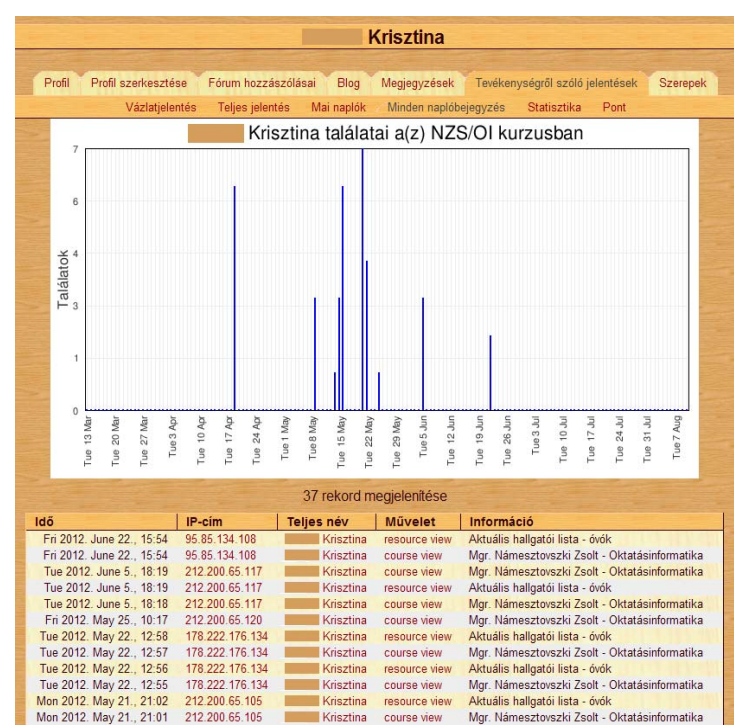

Figure 3. Detailed report of a user`s activity in Moodle

Feedback information about the success of learning and self-assessment is a vital part of each learning environment. There is a large variety of question types on Moodle, including multiple choice, true-false, and short answer questions. These questions are kept in the Question bank and can be re-used in different quizzes. Quizzes can be configured to allow multiple attempts. Each attempt at a question is automatically marked, and the teacher can choose whether to give feedback and/or show the correct answers [7]. From the Question bank the system can create randomly selected quizzes. The number of questions, the time limit, the grading scores and the numerical and textual grading are also modifiable. The number of attempts, time, score and the mark are attached to the profile of the user and can be displayed in separated reports.

\begin{tabular}{|c|c|c|}
\hline \multirow{2}{*}{$\begin{array}{c}\text { Hátralevōi idö } \\
\text { 0:19:07 } \\
\end{array}$} & \multicolumn{2}{|r|}{ NZS/OI - Elektronikus próbateszt előzetes megtekintése } \\
\hline & & Ürakezdés \\
\hline \multicolumn{3}{|c|}{ Mi jellemzö az intemetes tôrumokra? } \\
\hline \multirow[t]{4}{*}{ Valasszon egy válast. } & 0 & a. Hasonló érdeklödési kôrú embereket ôsszegyưữo webes forma. \\
\hline & 0 & b. A szociális hálók mintajajra készztett közösségi oldal. \\
\hline & 0 & c. A audiovizuális kommunikációt elósegitỏ weblap. \\
\hline & 0 & d. A multimédás kommunikációra éptỗ webes forma. \\
\hline \multicolumn{3}{|c|}{ Válasszza ki a leghelyesebb mondatot! } \\
\hline \multirow[t]{4}{*}{ Válasszon egy valasst. } & 0 & a. A hipertext, az emberi agyhoz hasonoloan, az asszociativi kapcsolatok kiépitésére elapszzik \\
\hline & 0 & b. A hipertext, az emberi agyhogy hasonlban, tetszöleges kapcsolatok kilakkilassira alapszik \\
\hline & 0 & c. A hipertext az emberi kiváncsisiág alapjän határozza meg a log kai kapcsolatokat. \\
\hline & 0 & 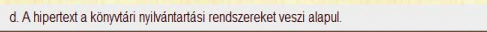 \\
\hline
\end{tabular}

Figure 4. Online quiz with multiple choice. Course: IT in education. The remaining time can be seen in the upper top corner (is the visible the remaining time)

\section{WORDPRESS}

WordPress is the most popular open source and free blogging software, based on PHP technology [5],[11], [12]. The basic unit in WordPress is Post, which is grouped under Pages. These Posts are created, edited or deleted by one or more (multi) person. The text and attached media can be added on the web based editing interface. The readers can write feedback information in the form of comments, which are accepted or deleted by administrator.

The advantages of this application include the large number of available templates, various accessories (plugin) widgets. One of the biggest advantages of this system is the flexible and efficient use of RSS technologies.

The administrator panel is available from mobile operation systems such as Android, iOS, Windows Phone.

WordPress can be used for presenting educational events (flexible use of media), reports (blogging), or for collecting feedback information.

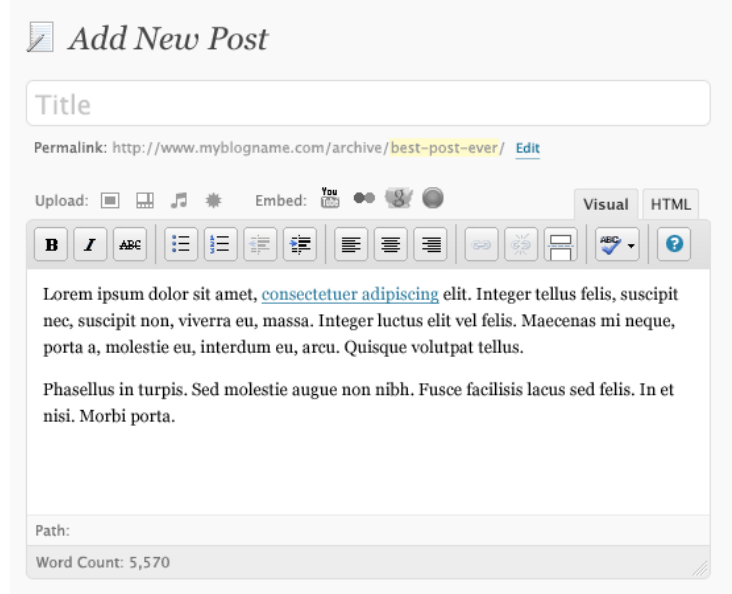

Figure 5. Tools Add New Post in Administrator Panel (Source: http://wpdotorg.files.wordpress.com/2008/10/newpost.png)

\section{CONCLUSIONS}

Moodle and WordPress are useful for supporting traditional educational process with e-learning tools, from upload educational material (text, pictures, presentation, animation) to support the whole interactive learning environment.

The greatest advantages of Moodle are: it is easy to configure roles and rights, as well as easily adaptable to traditional courses.

The greatest advantages of WordPress are: blog organized posts, feedback information (comments), large number of templates, widgets and plug-in and the support of modern applications such as mobile operation system and RSS.

It is the belief of the author that the best outcomes can be achieved by the joint use of both systems.

\section{REFERENCES}

[1] G. Eason, B. Noble, and I. N. Sneddon, "On certain integrals of Lipschitz-Hankel type involving products of Bessel functions," Phil. Trans. Roy. Soc. London, vol. A247, pp. 529-551, April 1955

[2] J. Clerk Maxwell, A Treatise on Electricity and Magnetism, $3^{\text {rd }}$ ed., vol. 2. Oxford: Clarendon, 1892, pp. 68-73

[3] I. S. Jacobs and C. P. Bean, "Fine particles, thin films and exchange anisotropy," in Magnetism, vol. III, G. T. Rado and H. Suhl, Eds. New York: Academic, 1963, pp. 271-350

[4] K. Elissa, "Title of paper if known," unpublished

[5] R. Nicole, "Title of paper with only first word capitalized", $J$. Name Stand. Abbrev., in press 
[6] Y. Yorozu, M. Hirano, K. Oka, and Y. Tagawa, "Electron spectroscopy studies on magneto-optical media and plastic substrate interface," IEEE Transl. J. Magn. Japan, vol. 2, pp. 740 741, August 1987 [Digests $9^{\text {th }}$ Annual Conf. Magnetics Japan, p. 301, 1982]

[7] M. Young, The Technical Writer's Handbook. Mill Valley, CA: University Science, 1989

[8] D. Glusac, Z. Namestovski (2008.): The Role of Digital Educative Material in Effective Teachings, Proceedings of the 8th WSEAS International Conference on Multimedia, Internet \& Video Technologies (MIV '08) \& Proceedings of the $8^{\text {th }}$ WSEAS International Conference on Distance Learning and Web Engineering (DIWEB '08); Santander, Cantabria, Spain

[9] Nadrljanski, Đ. (2007): Svetski trendovi obrazovanja na daljinu, Obrazovanje na daljinu, obrazovanje na daljinu, Trendovi trendovi u obrazovanju u obrazovanju

[10] Námesztovszki, Zs., Takács, M. (2008): Digital Course Supported Education In Life Long Learning Process; 9th International Symposium of Hungarian researchers on Computational intelligence and informatics, Budapest Tech Hungary - Hungarian Fuzzy Association; Budapest, Hungary

[11] http://moodle.org/stats, 2012

[12] http://w3techs.com/technologies/overview/content_management/al

[13] http://docs.moodle.org - MoodleDocs (2012)

[14] http://docs.moodle.org/20/en/Quiz_module - Quiz module MoodleDocs (2012)

[15] http://docs.moodle.org/22/en/Moodle site - basic structure Moodle site - basic structure - MoodleDocs (2012)

[16] http://docs.moodle.org/22/en/Non-editing teacher_role - Nonediting teacher role - MoodleDocs (2012)

[17] http://docs.moodle.org/23/en/Course_creator_role - Course creator role - MoodleDocs (2012)

[18] http://docs.moodle.org/23/en/Student_role - Student role MoodleDocs (2012)

[19] http://wordpress.org - WordPress > Blog Tool, Publishing Platform, and CMS (2012) 